[Regular Paper]

\title{
Effect of Support Particle Morphology of Ni Catalysts on Growth of Carbon Nanotubes by Methane Decomposition
}

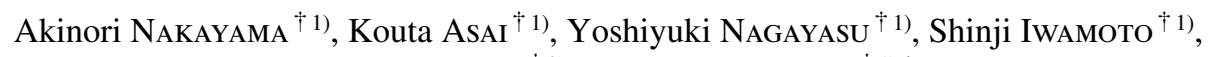 \\ Eriko YAGASAKI $^{\dagger 2}$, and Masashi INOUE ${ }^{\dagger 1)} *$ \\ $† 1)$ Dept. of Energy and Hydrocarbon Chemistry, Graduate School of Engineering, Kyoto University, Katsura, Kyoto 615-8510, JAPAN \\ ${ }^{\dagger 2)}$ Energy Use R\&D Center, The Kansai Electric Power Co., Inc., 3-11-20 Nakoji, Amagasaki, Hyogo 661-0974, JAPAN
}

(Received January 20, 2006)

\begin{abstract}
The effect of the morphology of the support particles on nickel-catalyzed decomposition of methane into carbon nanotubes and hydrogen was explored using a thermogravimetric apparatus. $\operatorname{Er}_{3} \mathrm{Ga}_{5} \mathrm{O}_{12}$ synthesized by the glycothermal method was used as the support of the Ni catalyst. As calcination temperature increased, morphology and pore-size distribution of $\mathrm{Er}_{3} \mathrm{Ga}_{5} \mathrm{O}_{12}$ changed. High carbon nanotube yield was attained over Ni catalyst supported on $\mathrm{Er}_{3} \mathrm{Ga}_{5} \mathrm{O}_{12}$ particles with spherical shape and smooth surfaces. Various aluminas were also examined for the support of the Ni catalysts. Quite high carbon yield was observed over Ni catalyst supported on spherical $\mathrm{Al}_{2} \mathrm{O}_{3}$ particles (Nanophase Technologies Corp.). Spherical support particles with smooth surfaces touch at a point, so can change positions easily. Therefore, the most important factor governing the carbon yield is the morphology of the catalyst support.
\end{abstract}

\section{Keywords}

Methane decomposition, Nickel catalyst, Carbon nanotube, Glycothermal method, Erbium gallium garnet, Support morphology

\section{Introduction}

Carbon nanotubes have attracted much interest since discovery ${ }^{1), 2)}$, because of their unique outstanding properties $^{3) \sim 5)}$. Carbon nanotubes are very remarkable materials with many potential applications including fillers for polymers ${ }^{6}$, , anodes for lithium rechargeable batteries $^{7)}$, catalytic support materials ${ }^{8)}$, and hydrogen storage media ${ }^{9)}$. Tremendous progress has been made in the synthesis of carbon nanotubes. Carbon nanotubes can be manufactured using laser-ablation ${ }^{10)}$, arcdischarge ${ }^{11)}$, or catalytic decomposition of hydrocarbons $^{12)}$. Among these methods, catalytic decomposition of methane, the main component of natural gas, seems to be the most efficient for large-scale and low-cost synthesis ${ }^{13) \sim 15)}$.

We previously reported that $\mathrm{Ni}$ catalyst supported on glycothermally-synthesized zirconia is one of the most effective catalysts for catalytic decomposition of methane into carbon nanotubes and hydrogen ${ }^{16)}$. We believe that the spherical morphology of glycothermallyprepared zirconia particles is one of the important factors. Therefore, the present study examined the catalytic decomposition of methane over Ni catalysts

\footnotetext{
* To whom correspondence should be addressed.

* E-mail: inoue@scl.kyoto-u.ac.jp
}

supported on spherical particles of erbium gallium garnet, synthesized by the glycothermal method.

Glycothermal synthesis of rare earth gallium garnets has been explored in our laboratory ${ }^{17) \sim 19)}$. For the rare earth elements with large ionic sizes, crystal growth of the garnet proceeds relatively slowly, yielding spherical particles with smooth surfaces. On the other hand, for the rare earth elements with small ionic sizes, crystal growth of the garnet takes place quite rapidly and monodispersed spherical particles can be obtained by adjusting the experimental conditions. However, the particles have apparently polycrystalline outlines with rough surfaces, although each particle is grown from one nucleus ${ }^{19)}$. Erbium gallium garnet is the latter type and the morphology can be changed by increasing calcination temperature. Therefore, this study investigated erbium gallium garnet as a support to examine the relationship between the support morphology and the carbon yield.

\section{Experimental}

Erbium gallium garnet was prepared by the glycothermal (GT) method ${ }^{17) \sim 19)}$. Required amounts of $\mathrm{Er}\left(\mathrm{CH}_{3} \mathrm{COO}\right)_{3} \cdot 4 \mathrm{H}_{2} \mathrm{O}$ and $\mathrm{Ga}(\mathrm{acac})_{3}$ were suspended in 1,4-butanediol in a test tube, serving as autoclave linear, and the test tube was placed in a $300-\mathrm{ml}$ autoclave. 


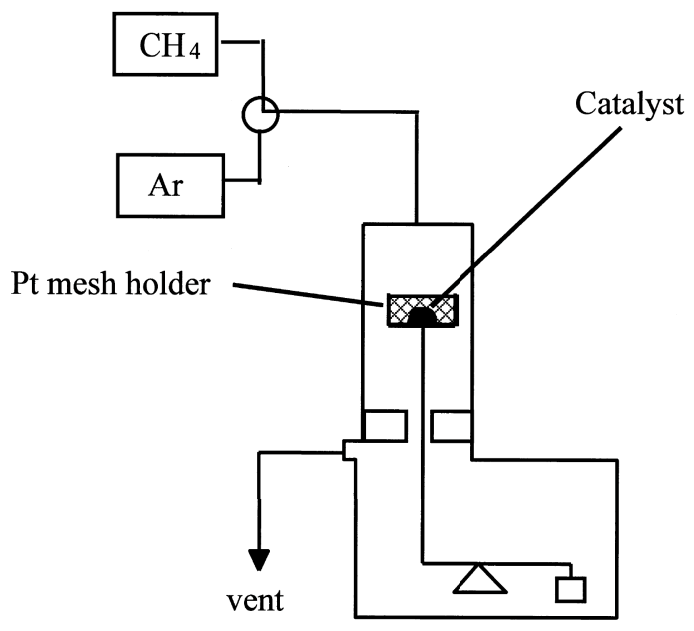

Fig. 1. Apparatus for Methane Decomposition

The autoclave was thoroughly purged with nitrogen and heated to $300^{\circ} \mathrm{C}$ at $2.3^{\circ} \mathrm{C} / \mathrm{min}$ and kept at that temperature for $2 \mathrm{~h}$. The product was collected by centrifuging, washed with methanol, dried in air, and then calcined at various temperatures $(700,850,1000,1100$, and $1200^{\circ} \mathrm{C}$ ) for $30 \mathrm{~min}$. $\gamma$-Alumina support was prepared by calcination of pseudoboehmite (Vista Chemical Co.). Spherical $\mathrm{Al}_{2} \mathrm{O}_{3}$ (Nanophase Technologies Corp.) and $\mathrm{Al}_{2} \mathrm{O}_{3}$ (JRC-ALO-8) were also used as catalyst supports. Catalysts were prepared by the impregnation method using an aqueous solution of nickel nitrate with the total Ni loading of $10 \mathrm{wt} \%$. After impregnation, the catalysts were calcined at $400^{\circ} \mathrm{C}$ for $30 \mathrm{~min}$.

Methane decomposition was carried out in a thermogravimetric apparatus (Rigaku Corp., TAS8110) (Fig. 1). The catalyst (20 mg) was set in a Pt mesh holder and heated in an argon flow $(10 \mathrm{~m} / / \mathrm{min})$ to the reaction temperature $\left(650^{\circ} \mathrm{C}\right)$, and the gas flow was changed to methane $(40 \mathrm{ml} / \mathrm{min})$ to start decomposition of methane. The weight gain due to carbon formation was monitored during the reaction, and the reaction was continued until the weight gain ceased. The rate of carbon formation was calculated from the initial slope of the weight gain curve, and the carbon yield was directly obtained from the weight gain at the end of the reaction.

The morphology of the carbon deposited by methane decomposition was observed using a transmission electron microscope (TEM), Hitachi H-800, operated at $200 \mathrm{kV}$. Carbon without purification was used for TEM experiments; so the samples contained catalyst materials. The nitrogen adsorption isotherm was determined using a volumetric sorption system, Yuasa Ionics Inc., Autosorb-1. Pore size distribution was calculated from the desorption branch of the nitrogen adsorption isotherm using the BJH method.

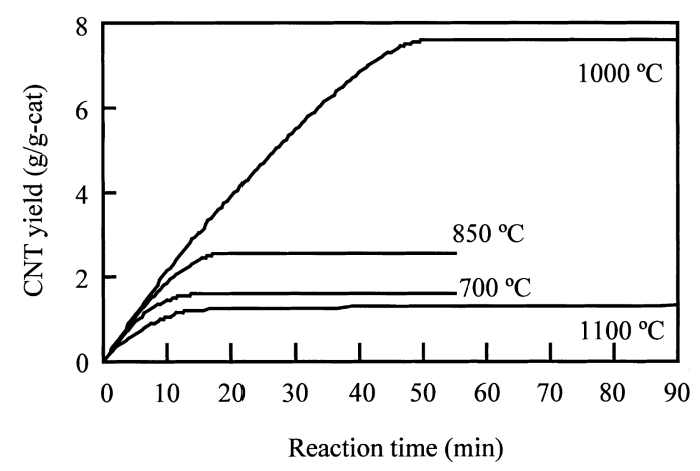

Fig. 2. Weight Gain due to Carbon Formation at $650^{\circ} \mathrm{C}$ over $10 \mathrm{wt} \%$ Ni Catalyst Supported on Glycothermally-prepared $\mathrm{Er}_{3} \mathrm{Ga}_{5} \mathrm{O}_{12}$ Calcined at Various Temperatures

\section{Results and Discussion}

3. 1. Methane Decomposition over $\mathrm{Ni} / \mathrm{Er}_{3} \mathrm{Ga}_{5} \mathrm{O}_{12}$

Methane decomposition was carried out at $650^{\circ} \mathrm{C}$ over the Ni catalysts supported on glycothermallyprepared $\mathrm{Er}_{3} \mathrm{Ga}_{5} \mathrm{O}_{12}$ calcined at various temperatures. Although the initial rates of carbon formation were almost the same regardless of calcination temperature (700-1100 $\mathrm{C}$ ), the carbon yield varied significantly with the calcination temperature of the support and increased as the calcination temperature increased from $700^{\circ} \mathrm{C}$ to $1000^{\circ} \mathrm{C}$ (Fig. 2). The support calcined at $1000^{\circ} \mathrm{C}$ gave the highest carbon yield $(7.60 \mathrm{~g} / \mathrm{g}$-cat), which was twice as high as the carbon yield of the catalyst supported on glycothermally-synthesized zirconia (3.47 g/ g-cat), which showed the highest carbon yield in our previous study ${ }^{16)}$. The carbon yield drastically decreased when the support calcined at $1100^{\circ} \mathrm{C}$ was used. Although $\mathrm{Er}_{3} \mathrm{Ga}_{5} \mathrm{O}_{12}$ had been scarcely examined for the catalyst supports, it showed relatively high performance for $\mathrm{Ni}$-catalyzed methane decomposition when optimally prepared.

Figure 3 shows the TEM images of carbon nanotubes formed on the catalysts with the supports calcined at various temperatures. The products formed on all catalysts were tube-like carbons. Amorphous carbons were rarely observed. The outer diameter of carbon nanotubes formed on the catalyst with the supports calcined at $700,850,1000$, and $1100^{\circ} \mathrm{C}$ were $30-60 \mathrm{~nm}$, 30-60 nm, 20-50 nm, and 20-70 nm, respectively.

\section{2. Change of Morphology of $\mathrm{Er}_{3} \mathrm{Ga}_{5} \mathrm{O}_{12}$ with Increasing Calcination Temperature}

Figure 4 shows X-ray diffraction (XRD) patterns of erbium gallium garnet calcined at various temperatures. The as-synthesized product already showed the peaks due to the garnet-type structure, and no other peaks were observed. Calcination did not alter the XRD pattern, although the peaks were sharpened by increasing calcination temperature.

Figure 5 shows the TEM images of $\mathrm{Er}_{3} \mathrm{Ga}_{5} \mathrm{O}_{12}$ parti- 
(a)

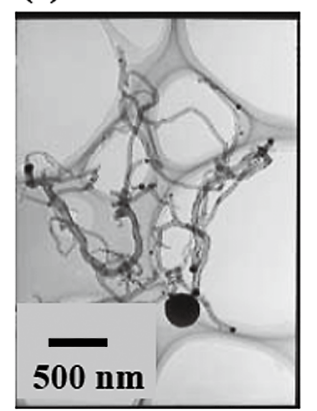

(c)

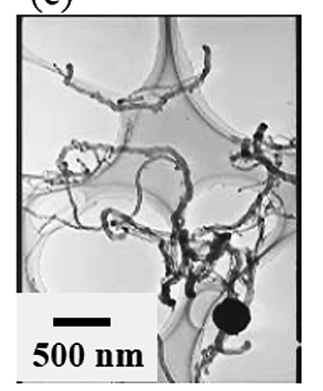

(b)

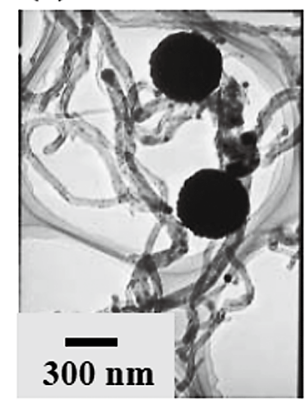

(d)

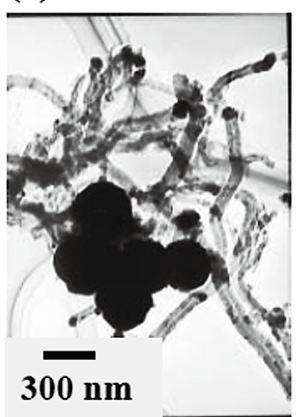

Fig. 3. TEM Images of Carbon Formed over $10 \mathrm{wt} \% \mathrm{Ni}$ Catalysts Supported on $\mathrm{Er}_{3} \mathrm{Ga}_{5} \mathrm{O}_{12}$ Calcined at: (a), $700^{\circ} \mathrm{C}$; (b), $850^{\circ} \mathrm{C}$; (c), $1000^{\circ} \mathrm{C}$; and (d), $1100^{\circ} \mathrm{C}$

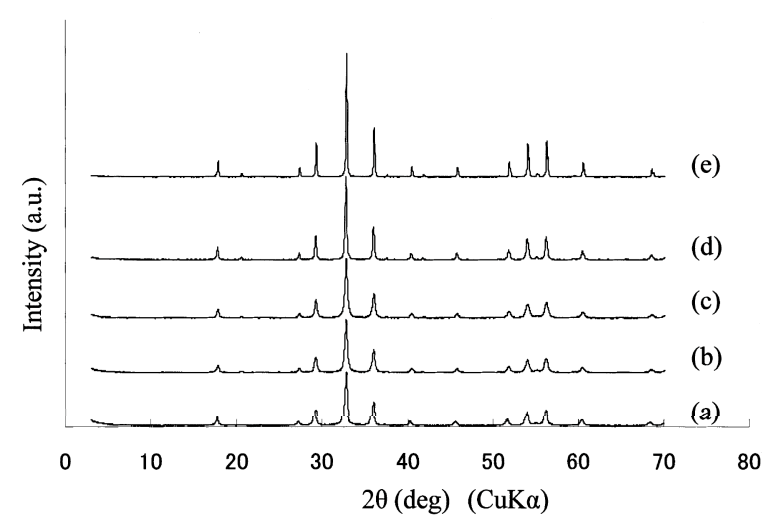

Fig. 4. XRD Patterns of $\mathrm{Er}_{3} \mathrm{Ga}_{5} \mathrm{O}_{12}$ : (a), As-synthesized; (b)-(e), Calcined at: (b), $700^{\circ} \mathrm{C}$; (c), $850^{\circ} \mathrm{C}$; (d), $1000^{\circ} \mathrm{C}$; and (e), $1200^{\circ} \mathrm{C}$

cles calcined at various temperatures. The assynthesized $\mathrm{Er}_{3} \mathrm{Ga}_{5} \mathrm{O}_{12}$ particles had spherical and polycrystalline outlines, and the particle size was distributed in a narrow range $(\sim 300 \mathrm{~nm})$. However, highmagnification TEM observation of the particles showed that whole particle was covered with a single lattice fringe, suggesting that each spherical particle was actually a single crystal grown from only one nucleus ${ }^{19}$. The selected area electron diffraction pattern of an $\mathrm{Er}_{3} \mathrm{Ga}_{5} \mathrm{O}_{12}$ particle also indicated the single crystalline nature of the particle, but the diffraction spot was com-

(a)

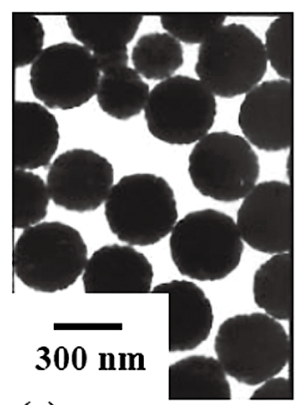

(c)

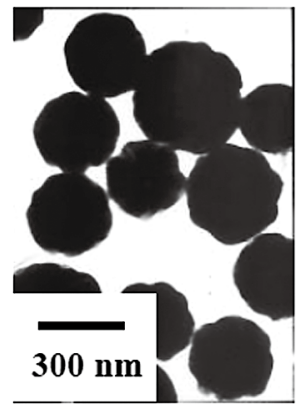

(b)

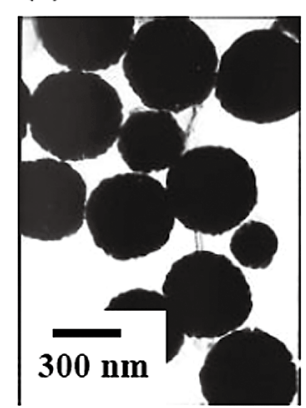

(d)

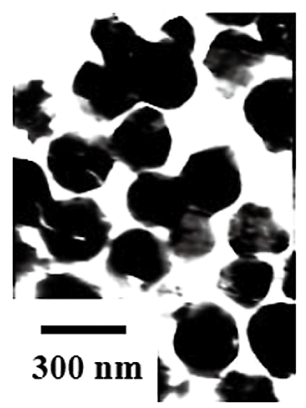

Fig. 5. TEM Images of $\mathrm{Er}_{3} \mathrm{Ga}_{5} \mathrm{O}_{12}$ Calcined at: (a), $700^{\circ} \mathrm{C}$; (b), $850^{\circ} \mathrm{C}$; (c), $1000^{\circ} \mathrm{C}$; and (d), $1100^{\circ} \mathrm{C}$

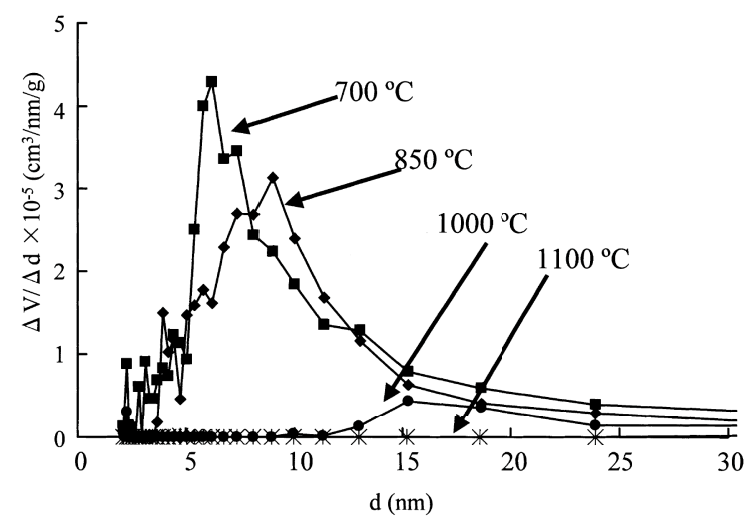

Fig. 6. BJH Pore-size Distribution of $\mathrm{Er}_{3} \mathrm{Ga}_{5} \mathrm{O}_{12}$ Calcined at Various Temperatures

posed of several subspots resulting in apparent polycrystalline outlines. The $\mathrm{Er}_{3} \mathrm{Ga}_{5} \mathrm{O}_{12}$ particles calcined at the temperature range of $700-1000^{\circ} \mathrm{C}$ were nearly spherical. As the calcination temperature increased, the surface of the particles became smooth, but the particle size was essentially unchanged. However, calcination of the sample at $1100^{\circ} \mathrm{C}$ caused partial sintering of the particles and large aggregates were observed (Fig. 5 (d)). On the other hand, the $\mathrm{ZrO}_{2}$ particles synthesized by the glycothermal method were $\sim 3 \mu \mathrm{m}$ sized spheres of aggregates of randomly-oriented primary particles having an average diameter of $4 \mathrm{~nm}$.

Figure 6 shows the pore-size distributions of the 


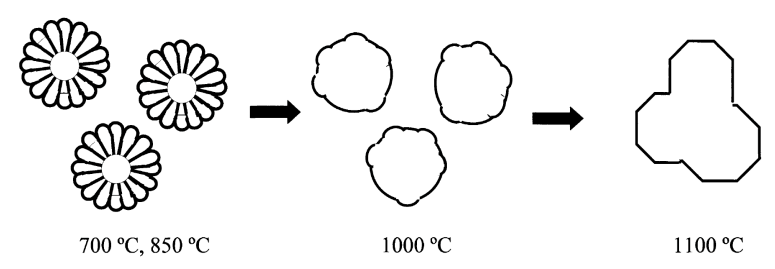

Fig. 7. Schematic Representation of the $\mathrm{Er}_{3} \mathrm{Ga}_{5} \mathrm{O}_{12}$ Particle Shape at Various Calcination Temperatures

$\mathrm{Er}_{3} \mathrm{Ga}_{5} \mathrm{O}_{12}$ particles calcined at various temperatures. The support particles calcined at $700^{\circ} \mathrm{C}$ had meso pores and the modal pore diameter was slightly enlarged by calcination at $850^{\circ} \mathrm{C}$. By calcination at temperatures $>1000^{\circ} \mathrm{C}$, the meso pores disappeared and the support particles had negligible pore volumes. This finding accords with the morphological change of the support particles. The particles calcined at 700 and $850^{\circ} \mathrm{C}$ had meso pores resulting from deep crevices between crystallites. The particles calcined above $1000^{\circ} \mathrm{C}$ had smooth surfaces because of sintering between the crystallites in the particle. Therefore, no meso pore systems were detectable by the nitrogen adsorption method. The surface areas of $\mathrm{Er}_{3} \mathrm{Ga}_{5} \mathrm{O}_{12}$ calcined at 700, 850, 1000 , and $1100^{\circ} \mathrm{C}$, calculated from the nitrogen adsorption isotherm by the BET method, were 16, 9.7, 4.4, $2.4 \mathrm{~m}^{2} / \mathrm{g}$, respectively. The crevices in the samples calcined at lower temperatures had relatively large surface areas.

Figure 7 illustrates the model of the morphological change of the support particles by calcination. The support particles calcined at 700 and $850^{\circ} \mathrm{C}$ were spherical, but had rough surfaces with deep crevices between the crystallites. The particles calcined at $1000^{\circ} \mathrm{C}$ were well-divided with smooth surfaces. Sintering between the particles occurred with calcination at $1100^{\circ} \mathrm{C}$, and the aggregated particles became irregularly shaped.

\section{3. Effect of the Morphology of the Support}

\section{Particles on Carbon Nanotube Growth}

It is generally accepted that the carbon nanotubes grow on the supported Ni catalysts by a tip-growth mechanism in methane decomposition ${ }^{20)}$. The Ni particles are detached from the supports and placed at the tips of carbon nanotubes. Carbon nanotubes grow as if lifting the Ni particles. At the early stage of methane decomposition, carbon nanotubes come in contact with other surrounding support particles. If the support particles are spherical and the surfaces are smooth, mobility is not restricted. On the other hand, if interaction between support particles due to surface energy is strong, mobility is restricted and carbon nanotube growth will be prevented because there are limited spaces between the particles. Spherical support particles touched one another at a point, easily allowing change in position (Fig. 8 (a)); therefore, the Ni catalysts supported on spherical particles showed high carbon (a)

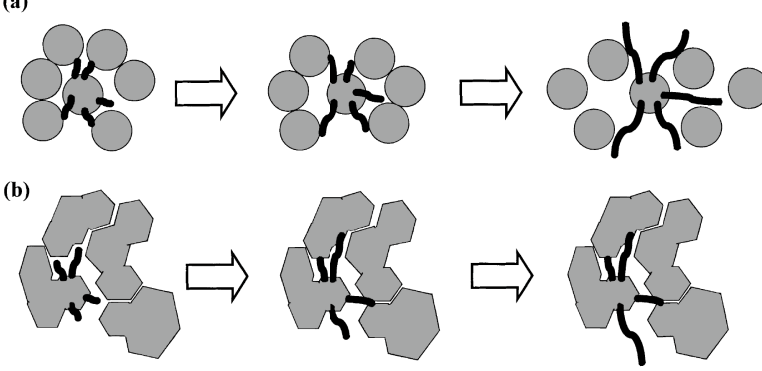

Support particles are: (a), spherical; and (b), not spherical.

Fig. 8. Schematic Representation of Carbon Formation at the Early Stage in Methane Decomposition

yields. The carbon yield increased as the calcination temperature increased from $700^{\circ} \mathrm{C}$ to $1000^{\circ} \mathrm{C}$ because the support surface became smoother. On the other hand, if the surfaces of the support particles were rough or the particles were irregularly shaped, mobility decreased because particles touched one another at a surface (Fig. 8 (b)). The growth of carbon nanotubes was stopped when the growing carbon nanotubes collided with other support particles. Therefore, the Ni catalysts supported on such particles showed low carbon yields. The Ni catalyst supported on the $1100^{\circ} \mathrm{C}$ calcined sample showed much lower carbon yield than the catalyst supported on the $1000^{\circ} \mathrm{C}$ calcined sample because the support particles were aggregated and irregularly shaped.

The crystallite sizes of $\mathrm{NiO}$ supported on the $\mathrm{Er}_{3} \mathrm{Ga}_{5} \mathrm{O}_{12}$ samples were calculated from the XRD patterns by the Scherrer equation as $20.5,18.6,13.7$, and $10.0 \mathrm{~nm}$ for the supports calcined at 700, 850, 1000, and $1200^{\circ} \mathrm{C}$, respectively. The particle sizes of $\mathrm{NiO}$ supported on the $\mathrm{Er}_{3} \mathrm{Ga}_{5} \mathrm{O}_{12}$ observed by TEM accorded with the crystallite sizes calculated from XRD patterns. The particle size of $\mathrm{NiO}$ was apparently controlled by the drying speed of the impregnated solution from which $\mathrm{Ni}\left(\mathrm{NO}_{3}\right)_{2}$ crystals are deposited. Slow drying speed gave larger crystals of $\mathrm{Ni}\left(\mathrm{NO}_{3}\right)_{2}$. However, no relationship was found between the particle size of $\mathrm{NiO}$ and the carbon yield. The highest carbon yield was attained with the support calcined at $1000^{\circ} \mathrm{C}$, but the carbon yield drastically decreased with the support calcined at $1100^{\circ} \mathrm{C}$. Moreover, the $\mathrm{Ni}$ particles at the tips of carbon nanotubes were much larger than the particle size of $\mathrm{NiO}$, indicating that particle growth occurred at the initial stage of the reaction. This point will be discussed in a separate paper.

\section{4. Effect of Grinding the Support Particles on Carbon Nanotube Growth}

The $\mathrm{Er}_{3} \mathrm{Ga}_{5} \mathrm{O}_{12}$ particles calcined at $1200^{\circ} \mathrm{C}$ were ground for a long time to investigate the effect on the carbon nanotube growth over Ni catalysts. The morphology of the ground particles is shown in Fig. 9 (b). 
(a)

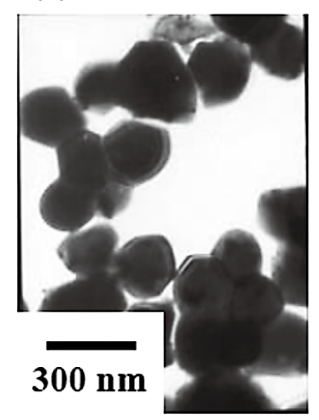

(b)

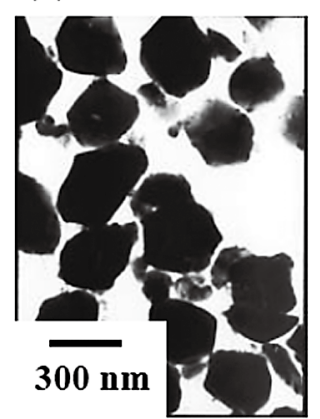

Fig. 9. TEM Images of $\mathrm{Er}_{3} \mathrm{Ga}_{5} \mathrm{O}_{12}$ Calcined at $1200^{\circ} \mathrm{C}$ : (a), Ascalcined and (b), Ground

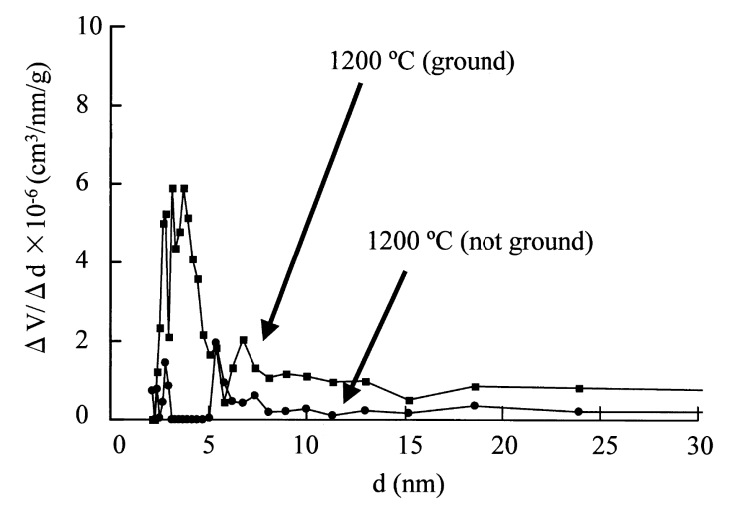

Fig. 10. Effect of Grinding on the BJH Pore-size Distribution of $\mathrm{Er}_{3} \mathrm{Ga}_{5} \mathrm{O}_{12}$ Calcined at $1200^{\circ} \mathrm{C}$

The shape of the ground particles was nearly spherical, indicating that the sintered $\mathrm{Er}_{3} \mathrm{Ga}_{5} \mathrm{O}_{12}$ particles were pulverized into the original particles by the grinding treatment. The BJH pore-size distribution (Fig. 10) shows that the sintered $\mathrm{Er}_{3} \mathrm{Ga}_{5} \mathrm{O}_{12}$ particles had essentially no pores, except a pore system with only a small pore volume formed by grinding. This pore system apparently resulted from the presence of small debris in the ground sample (Fig. 9 (b)). The BET surface areas of the original and the ground samples were 2.2 and $2.4 \mathrm{~m}^{2} / \mathrm{g}$, respectively. Therefore, the surface area of the debris in the latter sample was negligible. The carbon yield over the catalyst supported on the sintered $\mathrm{Er}_{3} \mathrm{Ga}_{5} \mathrm{O}_{12}$ particles was quite low $(0.843 \mathrm{~g} / \mathrm{g}$-cat $)$. On the other hand, the carbon yield over the catalyst supported on the ground $\mathrm{Er}_{3} \mathrm{Ga}_{5} \mathrm{O}_{12}$ particles was very high (5.55 g/g-cat). This result also supports the argument that the morphology of the catalyst support has the decisive effect on the carbon nanotube yield by the Nicatalyzed methane decomposition.

\section{5. Methane Decomposition over $\mathrm{Ni} / \mathrm{Al}_{2} \mathrm{O}_{3}$}

We also investigated methane decomposition over $\mathrm{Ni}$ catalysts supported on various aluminas. Figure 11 shows the morphology of the spherical alumina sample purchased from Nanophase Technologies Corp. All

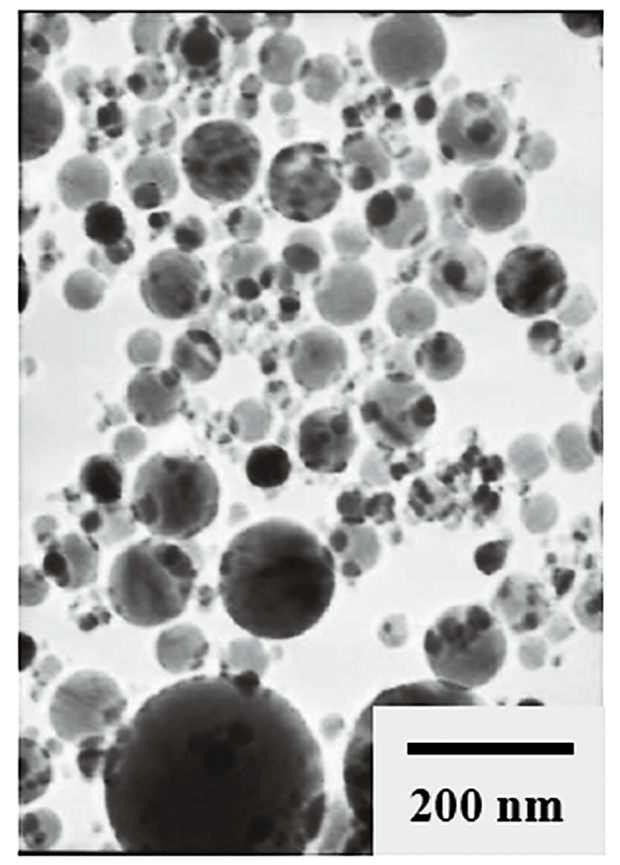

Fig. 11. TEM Image of Spherical $\mathrm{Al}_{2} \mathrm{O}_{3}$ (Nanophase Tech. Corp.)

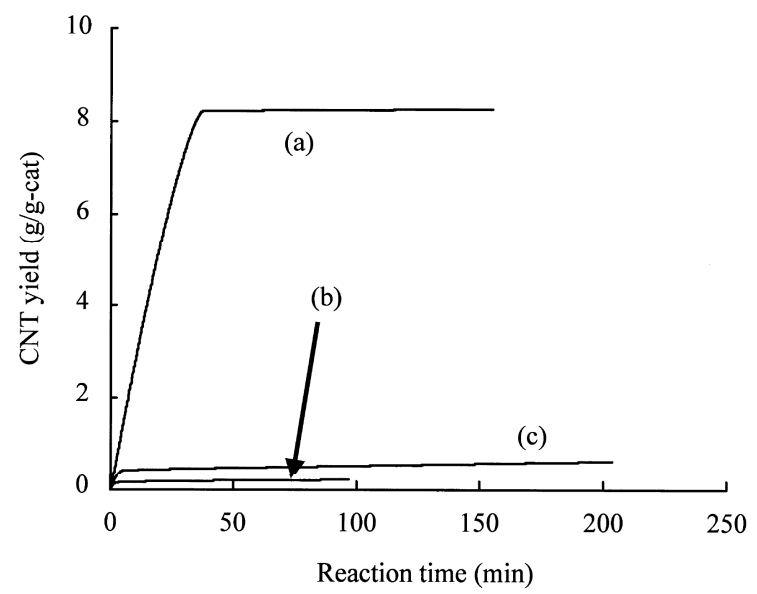

Fig. 12. Weight Gain due to Carbon Formation at $650^{\circ} \mathrm{C}$ over $10 \mathrm{wt} \%$ Ni Catalyst Supported on: (a), $\mathrm{Al}_{2} \mathrm{O}_{3}$ (Nanophase Tech. Corp.); (b), Synthesized $\gamma-\mathrm{Al}_{2} \mathrm{O}_{3}$; (c), $\mathrm{Al}_{2} \mathrm{O}_{3}$ (JRCALO-8)

particles were spherical, although the particle diameter varied widely. The crystal phase of this sample was assigned as $\gamma$ - and $\theta$-alumina by XRD, whereas the BET surface area was $35 \mathrm{~m}^{2} / \mathrm{g}$. Figure 12 shows the weight gain due to carbon formation at $650^{\circ} \mathrm{C}$ over the $\mathrm{Ni}$ catalysts supported on various alumina samples. The Ni catalysts supported on the ordinary alumina particles (JRC-ALO-8 and synthesized $\gamma-\mathrm{Al}_{2} \mathrm{O}_{3}$ ) showed quite low carbon yields $(0.665$ and $0.105 \mathrm{~g} / \mathrm{g}$-cat, respectively). As expected, the Ni catalyst supported on spherical alumina particles gave a high carbon yield $(8.23 \mathrm{~g} / \mathrm{g}$-cat $)$. This result confirms that the Ni cata- 
(a)

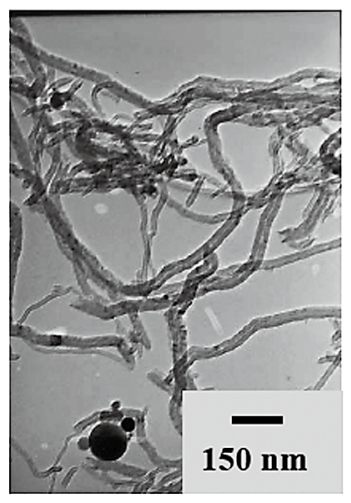

(c)

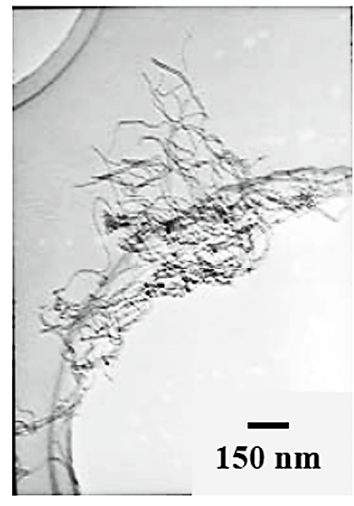

(b)

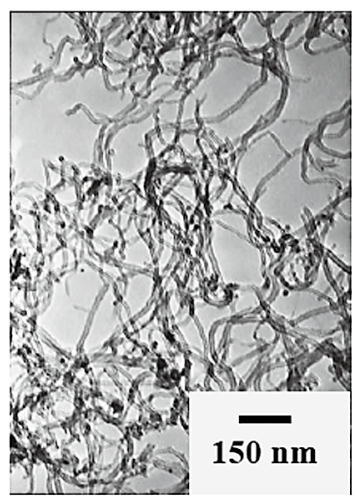

$\mathrm{ZrO}_{2}$ has a pore system, so the most important factor is not whether or not the support has the pore system but the morphology of the support particles which determines their mobility.

\section{Conclusion}

The present results clearly showed that the morphology of the catalyst support had a decisive effect on the carbon nanotube yield by the Ni-catalyzed decomposition of methane. Spherical support particles with smooth surfaces touch only at a point, so can change position easily. Therefore, they do not prevent carbon nanotube growth. On the other hand, support particles which are irregularly shaped or have rough surfaces touch at surfaces and large energy is required to move the support particles. Therefore, Ni catalysts supported on such particles provide low carbon yields. Therefore, the carbon yield by the Ni-catalyzed decomposition of methane is determined by physical factors, not by chemical or thermodynamical factors.

\section{References}

1) Iijima, S., Nature, 354, 56 (1991).

2) Iijima, S., Ichihasi, T., Nature, 363, 603 (1993).

3) Dekker, C., Phys. Today, 52, 22 (1999).

4) Park, C., Ounaies, Z., Watson, K. A., Crooks, R. E., Smith, J. Jr., Lowther, S. E., Connell, J. W., Sioichi, E. J., Harrison, J. S., Clair, T. L. St., Chem. Phys. Lett., 364, 303 (2002).

Fig. 13. TEM Images of Carbon Formed at $650^{\circ} \mathrm{C}$ over $10 \mathrm{wt} \% \mathrm{Ni}$ Catalysts Supported on: (a), $\mathrm{Al}_{2} \mathrm{O}_{3}$ (Nanophase Tech. Corp.); (b), Synthesized $\gamma-\mathrm{Al}_{2} \mathrm{O}_{3}$; (c), $\mathrm{Al}_{2} \mathrm{O}_{3}$ (JRC-ALO-8)

lysts supported on spherical particles show high activities in methane decomposition.

Figure 13 shows the TEM images of carbon deposited on the catalysts supported on the aluminas. Carbon nanotube was observed on all catalysts. The distributions of the outer diameters of carbon nanotubes formed on the catalysts with the synthesized $\gamma$-alumina, JRC-ALO-8, and spherical alumina were 10-20, 10-35 and 15-45 nm, respectively. The surface area of the synthesized $\gamma$-alumina and JRC-ALO- 8 were 183 and $158 \mathrm{~m}^{2} / \mathrm{g}$, respectively, which were much larger than that of the spherical alumina. Therefore, Ni particles were dispersed well on the synthesized $\gamma$-alumina and JRC-ALO-8 particles, and the small Ni particles formed thin carbon nanotubes. Fumed $\mathrm{SiO}_{2}(\mathrm{Cab}-\mathrm{O}-\mathrm{Sil}$ from CABOT Co.) has been proposed as the most effective support for Ni-catalyzed methane decomposition, possibly because the support has no pore structure ${ }^{21)}$. Carbon nanotubes formed in the pores would collide with other carbon nanotubes in the pores. We agree that the supports with smooth surfaces and no pore systems are effective for Ni-catalyzed methane decomposition. However, the glycothermally-prepared

5) Odom, T. W., Huang, J. L., Kim, P., Lieber, C. M., J. Phys. Chem. B, 104, 2794 (2000).

6) Dufresne, A., Paillet, M., Putaux, J. L., Canet, R., Carmona, F., Delhaes, P., Cui, S., J. Mater. Sci., 37, 3915 (2002).

7) Ishihara, T., Kawahara, A., Nishiguchi, H., Yoshio, M., Takita, Y., J. Power Sources, 97-98, 129 (2001).

8) Zhang, Y., Zhang, H., Lin, G., Chen, P., Yuan, Y., Tsai, K. R., Appl. Catal. A: General, 187, 213 (1999).

9) Takagi, H., Hatori, H., Soneda, Y., Yoshizawa, N., Yamada, Y., Mater. Sci. Eng. B, 108, 143 (2004).

10) Guo, T., Nikolaev, P., Thess, A., Colbert, D. T., Smalley, R. E., Chem. Phys. Lett., 243, 49 (1995).

11) Ebbesen, T. W., Ajayan, P. M., Nature, 358, 220 (1992).

12) Cui, S., Lu, C. Z., Qiao, Y. L., Cui, L., Carbon, 37, 2070 (1999).

13) Takenaka, S., Kobayashi, S., Ogihara, H., Otsuka, K., J. Catal., 217, 79 (2003).

14) Homma, Y., Kobayashi, Y., Ogino, T., Appl. Phys. Lett., 81, 2261 (2002).

15) Hirata, A., Yoshioka, N., Tribology Int., 37, 893 (2004).

16) Nagayasu, Y., Nakayama, A., Kurasawa, S., Iwamoto, S., Yagasaki, E., Inoue, M., J. Jpn. Petrol. Inst., 48, (5), 301 (2005).

17) Inoue, M., Kominami, H., Inui, T., Appl. Catal. A: General, 97, L25 (1993).

18) Inoue, M., J. Phys.: Condens. Matter, 16, S1291 (2004).

19) Inoue, M., Nishikawa, T., Otsu, H., Kominami, H., Inui, T., J. Am. Ceram. Soc., 81, 1173 (1998).

20) Baker, R. T. K., Barber, M. A., Harris, P. S., Feates, F. S., Waite, R. J., J. Catal., 26, 51 (1972).

21) Takenaka, S., Ogihara, H., Yamanaka, I., Otuka, K., Appl. Catal. A: General, 217, 101 (2001). 
要旨

メタン分解反応によるカーボンナノチューブ成長における Ni 触媒担体の形状の影響

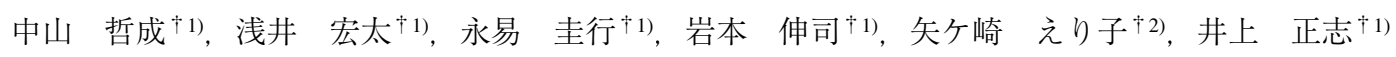

†1) 京都大学大学院工学研究科物質エネルギー化学専攻，615-8510 京都市西京区京都大学桂

†2) 関西電力 (株)エネルギー利用技術研究所, 661-0974 兵庫県尼崎市若王寺3-11-20

$\mathrm{Ni}$ 触媒を用いてメタン分解によりカーボンナノチューブと 水素を合成する反応に扔ける担体粒子の形状の影響を熱重量分 析装置を用いて検討した。Ni触媒の担体としてグリコサーマ ル法により合成した $\mathrm{Er}_{3} \mathrm{Ga}_{5} \mathrm{O}_{12}$ を用いた。 $\mathrm{Er}_{3} \mathrm{Ga}_{5} \mathrm{O}_{12}$ の形状と細 孔径分布は焼成温度により変化し, 球形で滑らかな表面を持つ $\mathrm{Er}_{3} \mathrm{Ga}_{5} \mathrm{O}_{12}$ 粒子に担持した $\mathrm{Ni}$ 触媒を用いた時, カーボンナノ チューブの生成量は高くなった。また，様々なアルミナを $\mathrm{Ni}$
触媒の担体として用いた。球状アルミナ (Nanophase Technologies Corp.) に担持した Ni 触媒は極めて高い炭素生成量を示 した。担体が球状で, 滑らかな表面を持つ時, 担体同士は点接 触するため, 容易に位置を変えることができる。このことから 触媒担体の形状は炭素生成量を支配する最も重要な因子である と結論付けられた。 